Удк $631.95: 633.11$

\title{
ВПЛИВ БУФЕРНОЇ ЗДАТНОСТІ ҐРУНТІВ НА БІОАКУМУЛЯЦІЮ ВАЖКИХ МЕТАЛІВ ПШЕНИЦЕЮ ОЗИМОЮ У ЗОНІ ВПЛИВУ ТЕС
}

\author{
Л.І. Коноваленко \\ кандидат хімічних наук \\ Донецька державна сільськогосподарська дослідна станція НААН \\ (Україна, Донецька область, м. Покровськ; e-mail: cnzdiapw@ukr.net \\ О.Б. Бондарева \\ кандидат технічних наук, старший науковий співробітник \\ Донецька державна сільськогосподарська дослідна станція НААН \\ (Україна, Донецька область, м. Покровськ; e-mail: olbraun58dds@ukr.net \\ О.О. Вінюков \\ кандидат сільськогосподарських наук \\ старший науковий співробітник \\ Донецька державна сільськогосподарська дослідна станція НААН \\ (Україна, Донецька область, м. Покровськ; e-mail: alex.agronomist@gmail.com)
}

Вивчено вплив буферної здатності чорнозему звичайного на біоакумуляцію важких металів пшеницею озимою у зоні техногенного впливу ТЕС. Досліджено рухомість важких металів залежно від влісту гумусу в орному шарі грунту та їх накопичення в рослинах пшениці озимої в умовах техногенного навантаження в південно-східному промисловому регіоні. Висвітлено вміст валових і рухомих борм міді (Cu), ицинку (Zn), свинцую (Pb) i кадмію (Cd) у грунтах, шуо є найбільшими забруднювачами агроландшабтів Донецъкої обл. Уміст вказаних елементів визначали також у зерні і соломі пшениці озимої. Встановлено, що у грунтовому покриві Донецъкої обл. домінують чорноземи (74\% від усієї плоші сільсъкогосподарсъких угідъ), які характеризуютъся значною буберністю до важких металів; для чорнозему звичайного в зоні техногенного впливу Курахівсъкої TEC збільшення вмісту гумусу з 3,6 до 4,9\% сприяє зменшенню концентрацї рухомих Cu, Zn $i$ $\mathrm{Pb}$ майже в 2 рази. За изих умов уміст рухомого кадмію істотно не змінювався. За показниками ступеня рухомості в грунті важкі метали за доступністю для рослин розташовуються в ряд: $\mathrm{Cd}>\mathrm{Cu}>\mathrm{Zn}>\mathrm{Pb}$, тобто буферні властивості чорнозему звичайного є різними для кожного з досліджених елементів. Найвищу біологічну рухливість має ијнк. Уміст свинцю в грунті значно вищий порівняно з умістом кадмію, але коеgіиієнт біологічного поглинання кадмію є майже вдвічі вищим. Біогенні елементи, як-от мідъ $і$ иинк більше накопичуються в регенеративних органах, $а$ уміст свинию $i$ кадмію був вищим у соломі. Виявлено зменшення вмісту міді $i$ ицнку в зерні $i$ соломі пшениці озимої за зростання вмісту гумусу, одночасно вліст свинцю в зерні знизився на $22 \%$. Отримані результати надають змогу оиінити ризики забруднення зернової продукцї̈ важкими металами і прогнозувати можливість вирошування екологічно безпечної продукції в регіонах високого техногенного тиску.

Ключові слова: техногенне забруднення, буберність грунту, гумус, важкі метали, ступінъ рухомості, пшеницяя озима, зерно, солома, коеббіиієнт біологічного поглинання.

Постановка проблеми. Проблема вирощування екологічно безпечної сільськогосподарської рослинної продукції набула останнім часом значної актуальності внаслідок інтенсифікації процесів техногенезу. Екологічна небезпека рослинної продукції залежить від умісту надлишкових концентрацій полютантів, пріоритетну роль серед яких займають важкі метали (BM) - мідь, цинк, свинець, кадмій тощо [1]. Інтенсивний та довготривалий розвиток промисловості зумовив значне забруднення агроландшафтів, особливо в індустріальних регіонах ВМ. Це призвело до порушення екологічної рівноваги, що насамперед впливає на грунт та рослини, оскільки вони є головними акумуляторами BM. За таких умов відбувається порушення процесів мінералізації, зниження біологічної активності і самоочищення грунтів та їх буферної здатності зв'язувати токсиканти [2-4; 7]. Все це спричиняє передумови до значного нагромадження рухомих форм BM у грунті, до їх накопичення рослинами та міграції трофічними ланцюгами живлення. Тому міграція у грунтах BM, що впливають на їх властивості, родючість, екологічну безпеку рослинної продукції є однією з актуальних агроекологічних проблем сьогодення. 
Аналіз останніх досліджень і публікацій. Проблемою забруднення грунтів ВМ займались вітчизняні і зарубіжні вчені, серед яких В.В.Медведєв, А.І. Фатєєв, С.А. Балюк, M.М. Мірошниченко, Н.А. Макаренко, I.П. Кабата-Пендіас, M.А. Глазовська, В.Б. Ільїн та ін. Встановлено, що ступінь токсичності грунтів, забруднених BM, визначається не стільки валовим умістом, скільки рухомими формами, які беруть участь в біогенній міграції [2-8]. Значну увагу фрахівцями приділено розробці оцінки ступеня забруднення, його нормуванню, запропоновано різні підходи до градації грунтів за рівнями вмісту BM для виділення територій 3 підвищеними екологічними ризиками [2;3;9-12]. Проблемі надходження важких металів у грунт і рослини присвячена значна кількість наукових досліджень [4; $14 ; 15]$. Висока біопродуктивність грунту та реалізація сільськогосподарськими культурами генетичного потенціалу залежить не лише від вмісту і складу органічної речовини та основних елементів живлення, а й від рівня фрітотоксичності грунту, що проявляється в рухомості ВМ. Одним із чинників, що впливає на ці процеси, є буфрерність грунтів. Природа буферності грунтів до ВМ обумовлюється певним характером їх взаємодії з грунтовими компонентами. Висвітлено, що ВM накопичуються в різних компонентах органічної речовини грунтів [13]. Гумусові кислоти, володіючи високою ємністю катіонного обміну і здатністю до утворювання хелатних сполук, активно зв'язують фрактично всі ВМ.

Взаємодія BM із компонентами біосфери вивчається понад два десятиріччя, проте масштаби проблеми не зменшуються внаслідок тривалості їх дії і здатності до інтенсивного накопичення в агроландшафтах.

На основі статистичних моделей залежності вмісту рухомих форм хімічних елементів від властивостей грунтів доведено, що ВМ, які потрапляють у об'єкти довкілля внаслідок діяльності людини, переважно концентруються на глибині 0-10 см [16]. Це зумовлено зв'язуванням полютантів у гумусовому горизонті. Утворення міцних комплексних сполук з ВМ є одним з найважливіших механізмів закріплення цих токсикантів техногенного походження, що визначає буферні властивості грунтів до забруднення ними і залежать від вмісту гумусових речовин $[4 ; 11 ; 12]$.

У конкретних екологічних умовах кожному типу грунту з характерним йому рівнем біологічної активності і буфрерності відповідає тільки йому властива реакція на забруднення BM. Тому необхідно вивчення регіональних особливостей міграційної активності BM з урахуванням буферних властивостей грунтів.
Техногенне надходження BM у навколишнє природне середовище негативно впливає не тільки на грунти, але й на рослинність. Актуальність окресленого питання полягає ще й у тому, що рослинність є проміжною ланкою міграції BM між грунтом і організмом людини.

Виділення невирішених раніше частин загальної проблеми. Незважаючи на значний обсяг теоретичних і методологічних досліджень, низка питань щодо екологічної безпеки в аграрній сорері індустріальних регіонів з високим рівнем впливу техногенезу на агроландшафти досі залишаються мало опрацьованими. Недостатньо вивченими є питання процесів переходу BM із грунту в рослини, а також безпечності зерна, що вирощується в зоні впливу високого техногенного навантаження.

Метою дослідження є вивчення рухомості важких металів залежно від умісту гумусу в орному шарі грунту та їх накопичення в рослинах пшениці озимої в умовах техногенного навантаження в південно-східному промисловому регіоні.

Матеріали та методи. Методичну основу дослідження складають методи: польовий, лабораторний, вимірювальний, розрахунковопорівняльний, аналізу і синтезу. Дослідження проводили з використанням атестованих та стандартизованих в Україні методик.

У грунті досліджували вміст валових і рухомих фрорм міді $(\mathrm{Cu})$, цинку $(\mathrm{Zn})$, свинцю $(\mathrm{Pb})$ і кадмію (Cd), що є найбільшими забруднювачами агроландшафтів Донецької обл. Уміст цих елементів визначали також у зерні і соломі пшениці озимої.

Відбір зразків грунту проводили в шарі 0-20 см, відповідно до ДСТУ 4287:2004 «Якість грунту. Відбирання проб». Підготовку грунту для аналізу проводили за стандартними методиками. Проведено вивчення концентрації рухомих форм BM із застосуванням ацетатноамонійної буферної витяжки з рН 4,8 і витяжки з 1 м HCl. Такий підхід надає змогу прогнозувати міграцію ВМ у системі «грунт-рослина» [17]. Для визначення валового вмісту ВМ грунт розкладали із застосуванням суміші кислот $\mathrm{HCl}+\mathrm{HNO}_{3}+\mathrm{HF}$ з подальшим розчиненням залишку в розчині азотної кислоти.

Відбір рослинних зразків для проведення агрохімічних досліджень проводили згідно «Mетодичних вказівок по проведенню досліджень в довготривалих дослідах з добривами».

У рослинних зразках уміст ВМ визначали в їх зольних розчинах після спалювання методом сухої мінералізації. Визначення вмісту хімічних елементів (міді, цинку, свинцю і кадмію) у пробах грунтів, зерні і соломі пшениці озимої здійснювали з використанням аналітичного 
методу атомно-абсорбційної спектрофотометрії на приладі КАС-120 [18; 19].

Агрохімічні властивості грунтів визначали за відповідними методиками: загальний уміст гумусу — за Тюріним (ДСТУ 4289:2004 «Якість грунту. Методи визначання органічної речовини»), $\mathrm{pH}$ водної витяжки - потенціометрично, згідно ДСТУ ISO10390:2007.

Усі виміри проводили у трикратній повторності. Статистичну обробку результатів здійснювали за Б.А. Доспеховим [20].

Викладення основного матеріалу. Особливість індустріальних регіонів полягає в тому, що до антропогенних чинників впливу на показники буферності грунтів, крім агронавантажень (внесення добрив, використання засобів захисту рослин, зрошення тощо), додається також істотний чинник техногенезу. Значну кількість чинників, що впливають на міграцію BM у грунтах індустріальних регіонів, можна поділити на дві основні групи: екзогенні (якісні і кількісні характеристики джерел емісії промислових полютантів) і ендогенні (екологічні властивості грунту, що обумовлюють на рухомість BM і іх біодоступність рослинам).

Результати аналізу промислової діяльності на території Донецької обл. засвідчили про фрормування у регіоні потужної техносорери, що налічує промислові підприємства гірничодобувної, металургійної та хімічної промисловості, енергетики і машинобудування, а також родовища корисних копалин. Всі ці техногенні об'єкти розташовуються в безпосередній близькості до сільгоспугідь.

У грунтовому покриві Донецької обл. домінують чорноземи, що становлять близько $74 \%$ від усієї площі сільськогосподарських угідь області. Чорноземи, як відомо, характеризуються значною буферністю до ВМ. Поряд із тим для чорноземів, з огляду на високу ємність грунтово-геохімічних бар'єрів, характерним є посилення небезпеки нагромадження BM у гумусовому шарі $[4 ; 10 ; 11]$. Верхні гумусові горизонти міцно фіксують BM. Небезпека полягає в тому, що хімічне забруднення тривалий час може не виявлятися внаслідок буферністі грунту і одночасно бути потужним чинником руйнування біосфери загалом. Забруднення рослинної продукції ВМ багато в чому визначається спрямованістю процесів трансформації сполук цих елементів за надходження у грунт, наслідком чого є зміна ступеня доступності іх для кореневої системи рослин.

На прикладі чорнозему звичайного малогумусного легкосуглинкового на лесах у зоні техногенного впливу енергетичного виробництва (Курахівської ТЕС) було досліджено рухомість BM залежно від вмісту гумусу в орному шарі грунту та іх накопичення в зерні і соломі пшениці озимої. Для досліджень була вибрана пшениця озима, як основна зернова культура в зоні Степу. Дослідження проводили на полях ДП «ДГ «Забойщик» ДДСДС НААН» Великоновоселківського р-ну Донецької обл.

Експериментально встановлено (табл. 1), що вміст валових форм $\mathrm{Cd}$ і $\mathrm{Cu}$, а також рухомих форм $\mathrm{Cd}, \mathrm{Pb}, \mathrm{Zn}, \mathrm{Cu}$ в грунтах зони дії викидів ТЕС істотно не залежить від відстані до 30 км, і натомість значно залежить від напрямку пануючих вітрів, де і нагромаджуються BM.

Аерогенні емісії енергетичних виробництв, окрім BM, містять також значну кількість кислотних компонентів - оксиди азоту, сірки, які в атмосфері утворюють відповідні кислоти. Це впливає на фрізико-хімічні властивості складових викидів, може зумовлювати перехід ВМ із оксидів у більш розчинні сполуки, наприклад нітрати і сульфрати. За умов високого вмісту кислотних компонентів BM будуть розсіюватись у вигляді аерозолів на значні відстані від джерела забруднення.

Зразки грунту та основної і побічної рослинної продукції відбирали перед збиранням урожаю з двох полів, де попередньо було ви-

Таблииял 1

Уміст важких металів у грунті залежно від напрямку вітру і відстані від промислового об'єкта

\begin{tabular}{|l|c|c|c|c|c|}
\hline \multirow{2}{*}{\multicolumn{1}{|c|}{ Напрямок вітру }} & \multirow{2}{*}{ Відстань, км } & \multicolumn{4}{|c|}{ Уміст ВМ у грунтах, мг $/$ кг } \\
\cline { 3 - 6 } & & $\mathbf{C d}$ & $\mathbf{P b}$ & $\mathbf{Z n}$ & $\mathbf{C u}$ \\
\hline \hline зах., півн.-зах. & 10 & $0,9 / 0,12^{*}$ & $18 / 0,9$ & $64 / 6,1$ & $16 / 1,9$ \\
\hline зах., півн.-зах. & 20 & $0,7 / 0,09$ & $16 / 0,8$ & $58 / 5,6$ & $16 / 1,8$ \\
\hline зах., півн.-зах. & 30 & $0,8 / 0,10$ & $13,9 / 0,7$ & $55 / 5,6$ & $17 / 1,9$ \\
\hline півд., сх. & 10 & $0,3 / 0,06$ & $16 / 0,6$ & $47 / 4,8$ & $16 / 1,8$ \\
\hline півд., сх. & 20 & $0,3 / 0,05$ & $16 / 0,4$ & $44 / 4,6$ & $13,5 / 1,7$ \\
\hline
\end{tabular}

*Примітка: чисельник — валові форми ВМ, знаменник — рухомі форми ВМ ( $\mathrm{pH} 4,8)$. 
значено різний уміст гумусу. Результати аналітичних досліджень щодо характеристики грунтів наведено в табл. 2 .

Зразки досліджуваного грунту характеризувались нейтральною реакцією середовища. Вміст гумусу полів відрізнявся на $1,3 \%$ і становив 3,6 і 4,9\%. Відповідно до шкали буфрерності грунтів щодо ВМ за В.Б. Ільїним [21], такий уміст гумусу обумовлює різний рівень цього показника — відповідно 3,5 і 5 балів. Органічна речовина грунту обумовлює вплив на рухомість ВМ і, як наслідок, на їх доступність для рослин. Для міді, цинку і свинцю концентрація кислоторозчинних фрорм за збільшення вмісту гумусу зменшилась незначно, одночасно і вміст рухомих фрорм, доступних для рослин, знизився майже вдвічі (табл. 2). Щодо вмісту кислоторозчинних і рухомих форм кадмію, такої різниці не спостерігалось. Більш чітке уявлення про рухомість ВМ у грунті забезпечує кількісний показник рухомості - ступінь рухомості $(\omega, \%)$, який було розраховано за співвідношенням концентрації рухомих фрорм елемента i концентрації його кислоторозчинної фрорми.

За зростання вмісту гумусу в грунті з 3,6 до 4,9\% ступінь рухомості кадмію змінюється неістотно - становить 26,2 і $24,6 \%$ відповідно і має найбільше значення серед досліджених елементів. Одночасно за цих самих умов ступінь рухомості міді, свинцю і цинку зменшилась майже вдвічі. Отже, встановлено, що для чорнозему звичайного малогумусного за нейтральної реакції середовища вміст рухомих форм міді, цинку і свинцю істотно залежить від вмісту гумусу. Для кадмію вагомої залежності не відзначено. За показниками ступеня рухомості в грунті BM за доступністю для рослин розташовуються в ряд: $\mathrm{Cd}>\mathrm{Cu}>\mathrm{Zn}>\mathrm{Pb}$, тобто буферні властивості чорнозему звичайного $€$ різними для досліджуваних елементів.

Як відомо, рослини можуть вибірково поглинати і накопичувати елементи, необхідні для свого росту та розвитку. Експериментальні результати з визначення вмісту BM у основній і побічній продукції пшениці озимої наведено в табл. 3.

Уміст ВМ у зерні пшениці озимої не перевищував максимально допустимих рівнів для харчування дорослого населення [22], окрім кадмію, що у деяких зразках був в 1,5 раза вищим відповідно. Біогенні елементи, як-от мідь і цинк більше накопичувались в регенеративних

Таблиияя 2

Агрохімічні показники чорнозему звичайного малогумусного в зоні техногенного впливу ТЕС (відстань від джерела забруднення - 3 км)

\begin{tabular}{|c|c|c|c|c|c|c|c|c|c|c|c|c|c|c|}
\hline \multirow{3}{*}{ Зразок } & \multirow{3}{*}{$\underset{\text { гумусу, \% }}{\text { Вміст }}$} & \multirow{3}{*}{ pH } & \multicolumn{8}{|c|}{ Вміст ВМ, мг/кг } & \multicolumn{4}{|c|}{ Ступінь рухомості $\omega, \%$} \\
\hline & & & \multicolumn{2}{|c|}{$\mathbf{C u}$} & \multicolumn{2}{|c|}{$\mathbf{Z n}$} & \multicolumn{2}{|c|}{$\mathbf{P b}$} & \multicolumn{2}{|c|}{ Cd } & \multirow{2}{*}{$\mathbf{C u}$} & \multirow{2}{*}{$\mathbf{Z n}$} & \multirow{2}{*}{$\mathbf{P b}$} & \multirow{2}{*}{ Cd } \\
\hline & & & $1^{*}$ & 2 & 1 & 2 & 1 & 2 & 1 & 2 & & & & \\
\hline Грунт 1 & 3,6 & 7,0 & 8,6 & 1,0 & 18,3 & 1,7 & 4,5 & 0,42 & 0,65 & 0,17 & 11,9 & 9,3 & 9,3 & 26,2 \\
\hline Грунт 2 & 4,9 & 7,0 & 7,7 & 0,5 & 17,5 & 0,9 & 4,2 & 0,22 & 0,57 & 0,14 & 6,9 & 5,1 & 5,3 & 24,6 \\
\hline $\mathrm{HIP}_{05}$ & & & 0,9 & 0,2 & 1,6 & 0,4 & 0,3 & 0,09 & 0,11 & 0,06 & & & & \\
\hline
\end{tabular}

*Примітка: 1 — кислоторозчинна форма, 2 - рухома форма.

Таблицяя 3

Уміст важких металів у рослинах пшениці озимої

\begin{tabular}{|c|c|c|c|c|c|c|c|c|}
\hline \multirow{3}{*}{ Зразок } & \multicolumn{8}{|c|}{ Уміст ВМ у рослинній продукції, мг/кг } \\
\hline & \multicolumn{2}{|c|}{$\mathbf{C u}$} & \multicolumn{2}{|c|}{$\mathbf{Z n}$} & \multicolumn{2}{|c|}{$\mathbf{P b}$} & \multicolumn{2}{|c|}{ Cd } \\
\hline & 1 & 2 & 1 & 2 & 1 & 2 & 1 & 2 \\
\hline Грунт 1 & 7,1 & 4,8 & 36,2 & 23,8 & 0,50 & 0,81 & 0,15 & 0,28 \\
\hline Грунт 2 & 6,0 & 3,9 & 31,5 & 21,4 & 0,39 & 0,67 & 0,12 & 0,22 \\
\hline $\mathrm{HIP}_{0,5}$ & 0,7 & 0,5 & 2,6 & 1,3 & 0,08 & 0,10 & 0,01 & 0,01 \\
\hline МДР & 10 & & 50 & & 0,5 & & 0,10 & \\
\hline
\end{tabular}

*Примітка: 1 - зерно, 2 - солома; МдР — максимально допустимі рівні. 
Таблиия 4

Коефіцієнти біологічного поглинання важких металів пшеницею озимою

\begin{tabular}{|l|c|c|c|c|}
\hline \multirow{2}{*}{ Назва зразка } & \multicolumn{4}{|c|}{ Коефіцієнти біологічного поглинання } \\
\cline { 2 - 5 } & $\mathbf{C u}$ & $\mathbf{Z n}$ & $\mathbf{P b}$ & $\mathbf{C d}$ \\
\hline \hline Зерно & $0,78-0,83$ & $1,8-2,0$ & $0,09-0,11$ & $0,21-0,23$ \\
\hline Солома & $0,50-0,56$ & $1,2-1,3$ & $0,16-0,18$ & $0,39-0,43$ \\
\hline
\end{tabular}

органах порівняно з вегетативними органами. Свинець і кадмій, що відносяться до елементів першого класу небезпеки, навпаки, значно більше накопичувались в соломі, ніж у зерні. Встановлено зменшення вмісту міді і цинку в зерні і соломі пшениці озимої за зростання вмісту гумусу; вміст свинцю у зерні знизився на $22 \%$. Зниження надходження ВМ у рослини з грунтів з більшим умістом гумусу вірогідно зумовлено здатністю гумінових кислот адсорбувати іони металів. Крім високої катіонообмінної здатності, органічні речовини грунту можуть створювати міцні комплекси з BM, що не засвоюються рослинами.

Інтенсивність біоакумуляції ВМ рослинами оцінювали за допомогою коефіцієнта біологічного поглинання, який надає змогу дійти висновку про ступінь доступності елемента для рослин та про його міграцію в системі «грунт рослина». Коефіцієнт біологічного поглинання визначали за співвідношенням хімічного елемента в золі рослин і його вмісту у грунті [23]. Отримані результати наведено в табл. 4.

Результати аналізу коефіцієнтів біологічного поглинання надали змогу виявити деякі закономірності в біологічному накопиченні ВМ рослинністю з грунту. Дані табл. 4 свідчать, що найвищу біологічну рухомість має цинк. Уміст свинцю в грунті є значно вищим порівняно 3 умістом кадмію, але коефіцієнт біологічного поглинання кадмію, навпаки, - майже вдвічі вищий від відповідного показника щодо свинцю. Це, вірогідно, обумовлено наявністю у кореневої системи рослин бар'єрних властивостей щодо цього елемента.

Висновки. Для чорнозему звичайного малогумусного за нейтральної реакції середовища концентрація рухомих елементів, як-от міді, цинку і свинцю зменшується з підвищенням вмісту гумусу у грунті. Щодо кадмію, такої залежності не виявлено. За показниками ступеня рухомості в грунті BM розташовуються так: $\mathrm{Cd}>\mathrm{Cu}>\mathrm{Zn}>\mathrm{Pb}$, тобто буферні властивості чорнозему звичайного є відмінними для різних елементів.

Встановлено закономірності накопичення BM вегетативними і регенеративними органами пшениці озимої у зоні техногенного впливу TEC. Інтенсивність міграції міді і цинку в зерно є вищою, ніж у солому. Кадмію і свинцю більше накопичується в соломі, ніж у зерні. Щодо цинку, спостерігаєтьсяміграція BM із грунту в рослини, для кадмію і свинцю - розсіювання.

Отримані результати надають змогу оцінювати ризики забруднення зернової продукції BM і прогнозувати можливість вирощування екологічно безпечної продукції в регіонах високого техногенного тиску.

\section{СПИСОК ВИКОРИСТАНИХ ДЖЕРЕЛ}

1. Некос А.Н. Акумулятивні властивості рослин як фрактор фрормування екологічної безпеки рослинної харчової продукції (на прикладі Харківського регіону) // Людина та довкілля. Проблеми неоекології. 2012. № 1-2. C. 100-107.

2. Фатєєв А.І., Мірошниченко М.М., Самохвалова В.Л., Биндич Т.Ю. До питання оцінки рівнів небезпеки забруднення грунтів важкими металами // Вісник аграрної науки. 1999. № 10. С. 39-62.

3. Балюк С.А., Ладних В.Я., Мошник Л.В. Оцінка забруднення зрошувальної води та грунтів важкими металами // Вісник аграрної науки. 2003. № 1. С.65-68.

4. Кабата-Пендиас А., Пендиас Х. Микроэлементы в почвах и растениях. М., 1989. 493 с.

5. Фатєєв A.I., Лопушняк B.I. Вплив систем удобрення на рухомість кадмію в темно-сірому опідзоленому грунті західного лісостепу України // Агрохімія і грунтознавство. 2015. Вип. 82. С. $33-36$.

6. Балюк С.А., Ладних В.Я., Мошник Л.В. Стан та родючість земель Донбасу // Водне господарство України. 1997. № 6. С.17-19.

7. Самохвалова В., Фатєєв А., Лучникова Є., Ликова О. Еколого-геохімічні дослідження вмісту різних форм Co, Ni, Cr у грунтах різного генезису в Україні // Вісник Львівського університету. 2012. Вип. 60. C. $171-181$.

8. Балюк С.А., Медведєв В.В., Мірошниченко М.М. Екологічний стан грунтів України // Український географічний журнал. 2012. № 2. С. 38-42. 
9. Ряховский А.В., Кравченко В.Н. Содержание тяжелых металлов в почвах и растениях // Земледелие. 2004. № 4. C. $26-29$.

10. Суюндуков Я.Т., Шагиева Ю.А. Особенности загрязнения черноземов тяжелыми металлами // Аграрная наука. 2008. № 1. С. 10-14.

11. Глазовская М.А. Проблемы и методы оценки эколого-геохимической устойчивости почв и почвенного покрова к техногенным воздействиям // Почвоведение. 1999. № 1. С. 114-124.

12. Фатєєв А.І., Мірошниченко М.М., Бородіна Я.В. Нормування вмісту міцно фріксованих фрорм важких металів у грунтах // Вісник аграрної науки. 2011. № 9. С. 41-44.

13. Фатєєв А.І., Семенов Д.О., Мірошниченко М.М., Ликова О.А., Смірнова К.Б., Шемет А.М. Співвідношення сгк/сорк у грунтах України як показник рухомості мікроелементів // Вісник аграрної науки. 2013. Вип. 7. С. 16-19.

14. Алексеев Ю. В. Тяжелые металлы в почвах и растениях. М.: Агропромиздат, 1987. 142 с.

15. Ильин В.Б. Тяжелые металлы в системе «почва — растение». Новосибирск: Наука, 1991.151 с.

16. Жовинский Э.Я., Кураева И.В. Геохимия тяжелых металлов в почвах Украины. К.: Наук. думка, 2002. 347 c.

17. Агроекологічний моніторинг та паспортизація сільськогосподарських земель: методично-нормативне забезпечення / за заг. ред. В.П. Патики, О.Г. Тараріко. К.: Фітосоціоцентр, 2002. С. 35-37.

18. Якість грунту. Визначення вмісту рухомих сполук марганцю (цинку, кадмію, заліза, кобальту, міді, нікелю, хрому, свинцю) в грунті в буфрерній амонійно-ацетатній витяжці з рН 4,8 методом атомноабсорбційної спектрофотометрії: ДСТУ 4770.1:2007 — ДСТУ 4770.9:2007. [Чинний від 2007-04-28] Київ: Держспоживстандарт України, 2007. (Національні стандарти України).

19. Методические указания по определению тяжелых металлов в почвах сельскохозяйственных угодий и продукции растениеводства. М.: ЦИНАО, 1992. 61 с.

20. Доспехов Б.А. Методика полевого опыта. М.: Агропромиздат, 1985. 351 с.

21. Ильин В.Б. Оценка буферности почв по отношению к тяжелым металлам // Агрохимия. 1995. № 10. C. $109-113$

22. Пшениця. Технічні умови: ДСТУ 3768-2010. [Чинний від 2010-04-01] Київ: Держспоживстандарт України, 2010. (Національні стандарти України).

23. Перельман А.И., Касимов Г.Н. Геохимия ландшафртов. М.: Астрея, 1999. 768 с.

\section{Інформація про авторів}

Коноваленко Людмила Іванівна - кандидат хімічних наук, старший науковий співробітник відділу технологій виробництва сільськогосподарської продукції, Донецька державна сільськогосподарська дослідна станція НААН (Україна, 85307, Донецька область, м. Покровськ, вул. Захисників України, 1; e-mail: cnzdiapw@ukr.net)

Бондарева Ольга Браунівна — кандидат технічних наук, старший науковий співробітник, учений секретар, Донецька державна сільськогосподарська дослідна станція НААН (Україна, 85307, Донецька область, м. Покровськ, вул. Захисників України, 1; e-mail: olbraun58dds@ukr.net)

Вінюков Олександр Олександрович - кандидат сільськогосподарських наук, старший науковий співробітник, директор, Донецька державна сільськогосподарська дослідна станція Національної академії аграрних наук України (Україна, 85307, Донецька область, м. Покровськ, вул. Захисників України, 1; е-mail: alex.agronomist@gmail.com)

L.I. Konovalenko Candidate of Chemical Sciences Donetsk State Agricultural Science Station of NAAS (Ukraine, Hryshyne; e-mail: cnzdiapw@ukr.net)

O.B. Bondareva

Candidate of Technical Sciences, Senior Researcher Donetsk State Agricultural Science Station of NAAS (Ukraine, Hryshyne; e-mail: olbraun58dds@ukr.net) O.O. Vinyukov Candidate of Agricultural Sciences Donetsk State Agricultural Science Station of NAAS (Ukraine, Hryshyne; e-mail: alex.agronomist@gmail.com)

\section{INFLUENCE OF BUFFER ABILITY OF THE SOIL ON BIOACCUMULATION OF HEAVY METALS BY WINTER WHEAT IN THE ZONE OF INFLUENCE TPP}

The effect of the buffering ability of common chernozem on the bioaccumulation of heavy metals by winter wheat in the zone of technogenic impact of TPPs was studied. The mobility of heavy metals de- 
pending on the humus content in the arable layer of the soil and their accumulation in winter wheat plants under the conditions of anthropogenic load in the southeastern industrial region are studied. The content of gross and mobile forms of copper ( $\mathrm{Cu})$, zinc $(\mathrm{Zn})$, lead $(\mathrm{Pb})$ and cadmium $(\mathrm{Cd})$ in soils, which are the largest pollutants of agrolandscapes in Donetsk region, is highlighted. The content of these elements was also determined in the grain and straw of winter wheat. It is established that in the soil cover of Donetsk region. chernozems dominate (74\% of the total agricultural land), which are characterized by significant buffering to heavy metals; for ordinary chernozem in the technogenic zone of the Kurakhovskaya TPP, an increase in the humus content from 3.6 to $4.9 \%$ contributes to a decrease in the concentration of mobile $\mathrm{Cu}, \mathrm{Zn}$ and $\mathrm{Pb}$ by almost 2 times. Under these conditions, the content of mobile cadmium did not change significantly. In terms of the degree of mobility in the soil, heavy metals in terms of accessibility to plants are arranged in a row: $\mathrm{Cd}>\mathrm{Cu}>\mathrm{Zn}>\mathrm{Pb}$, that is, the buffer properties of ordinary chernozem are different for each of the elements studied. Zinc has the highest biological mobility. The lead content in the soil is much higher compared to the cadmium content, but the biological absorption coefficient of cadmium is almost twice as high. Biogenic elements such as copper and zinc accumulate more in regenerative organs, and the content of lead and cadmium was higher in straw. A decrease in the content of copper and zinc in grain and straw of winter wheat with an increase in the content of humus was revealed, while the content of lead in grain decreased by $22 \%$. The results obtained make it possible to assess the risks of contamination of grain products with heavy metals and to predict the possibility of growing environmentally friendly products in regions of high technological pressure.

Keywords: technogenic pollution, soil buffering, humus, heavy metals, mobility level, winter wheat, grain, straw, coefficient of biological absorption.

\section{REFERENCES}

1. Nekos, A.N. (2012). Akumulyatyvni vlastyvosti roslyn yak faktor formuvannya ekolohichnoyi bezpeky roslynnoyi kharchovoyi produktsiyi (na prykladi Kharkivs'koho rehionu) [Accumulative properties of plants as a factor of formation of ecological safety of plant food products (on an example of the Kharkiv region)]. Lyudyna ta dovkillya. Problemy neoekolohiyi [Man and environment. Issues of neoecology], 1-2, 100-107. (In Ukr.)

2. Fateev, A.I., Miroshnichenko, M.M., Samokhvalova, V.L. and Bindych, T.Yu. (1999). Do pytannya otsinky rivniv nebezpeky zabrudnennya gruntiv vazhkymy metalamy [On the question of assessment of levels of soil pollution by heavy metals]. Visnyk ahrarnoyi nauky [Bulletin of Agrarian Science], 10, 39-62. (In Ukr.)

3. Balyuk, S.A., Ladnykh, V.Ya. and Moshnik, L.V. (2003). Otsinka zabrudnennya zroshuval'noyi vody ta gruntiv vazhkymy metalamy [Estimation of pollution of irrigation water and soils by heavy metals]. Visnyk ahrarnoyi nauky [Bulletin of Agrarian Science], 1, 65-68. (In Ukr.)

4. Kabata-Pendias, A. \& Pendias, X. (1989). Mikrojelementy $v$ pochvah i rastenijah [Microelements in soils and plants]. Moscow: Mir. 493. (In Russ.)

5. Fateev, A.I. \& Lopushniak, V.I. (2015). Vplyv system udobrennya na rukhomist' kadmiyu v temnosiromu opidzolenomu grunti zakhidnoho lisostepu Ukrayiny [Influence of Fertilizer Systems on Cadmium Movement in Dark Gray Hardened Soils of Western Forest-Steppe of Ukraine]. Ahrokhimiya $i$ hruntoznavstvo [Agrochemistry and Soil Science], 82, 33-36. (In Ukr.)

6. Balyuk, S.A., Ladnykh, V.Ya. and Moshnik, L.V. (1997). Stan ta rodyuchist' zemel' Donbasu [Status and Fertility of the Donbas Land]. Vodne hospodarstvo Ukrayiny [Water Management of Ukraine], 6, 17-19. (In Ukr.)

7. Samokhvalova, V., Fateev, A., Luchnikova, E. and Lykova, O. (2012). Ekoloho-heokhimichni doslidzhennya vmistu riznykh form $\mathrm{Co}, \mathrm{Ni}, \mathrm{Cr}$ u gruntakh riznoho henezysu v Ukrayini [Ecological-geochemical studies of the content of various forms of $\mathrm{Co}, \mathrm{Ni}, \mathrm{Cr}$ in soils of different genesis in Ukraine]. Visnyk L'vivs'koho universytetu [Visnyk of Lviv National University], 60, 171-181. (In Ukr.)

8. Balyuk, S.A., Medvedev, V.V. and Miroshnichenko, M.M. (2012). Ekolohichnyy stan gruntiv Ukrayiny [Ecological state of soil of Ukraine]. Ukrayins'kyy heohrafichnyy zhurnal [Ukrainian Geographical Journal], 2, 38-42. (In Ukr.)

9. Ryakhovsky, A.V. \& Kravchenko, V.N. (2004). Soderzhaniye tyazhelykh metallov v pochvakh i rasteniyakh [The content of heavy metals in soils and plants]. Zemledeliye [Zemledelie], 4, 26-29. (In Russ.)

10. Suundukov, Y.T. \& Shagieva, Yu.A. (2008). Osobennosti zagryazneniya chernozemov tyazhelymi metallami [Features of contamination of chernozems by heavy metals]. Agrarnaya nauka [Agrarian science], 1, 10-14. (In Russ.)

11. Glazovskaya, M.A. (1999). Problemy i metody otsenki ekologo-geokhimicheskoy ustoychivosti pochv i pochvennogo pokrova k tekhnogennym vozdeystviyam [Problems and methods of estimation of ecological and geochemical stability of soils and soil cover to man-made impacts]. Pochvovedenie [Eurasian Soil Science], 1, 114-124. (In Russ.) 
12. Fateev, A.I., Miroshnichenko, M.M. and Borodin, Ya.V.(2011). Normuvannya vmistu mitsno fiksovanykh form vazhkykh metaliv u gruntakh [Rationing of the content of firmly fixed forms of heavy metals in soils]. Visnyk ahrarnoyi nauky [Bulletin of Agrarian Science], 9, 41-44. (In Ukr.)

13. Fateev, A.I., Semenov, D.O., Miroshnichenko, M.N., Lykova, O.A, Smirnova, K.B., Shemet, A.M. (2013). Spivvidnoshennya shk/sfk u gruntakh Ukrayiny yak pokaznyk rukhomosti mikroelementiv [Correlation of sgk/spk in soils of Ukraine as an indicator of mobility of trace elements]. Visnyk ahrarnoyi nauky [Bulletin of Agrarian Science], 7, 16-19. (In Ukr.)

14. Alekseev, Yu.V. (1987). Tyazhelyye metally v pochvakh i rasteniyakh [Heavy metals in soils and plants]. M.: Agropromizdat. 142. (In Russ.)

15. Ilyin, V.B. (1991). Tyazhelyye metally v sisteme "pochva - rasteniye» [Heavy metals in the system "soil plant»]. Novosibirsk: Science. 151. [in Russ.]

16. Zhovinsky, E.Y. \& Kuraeva, I.V. (2002). Geokhimiya tyazhelykh metallov v pochvakh Ukrainy [Geochemistry of heavy metals in the soils of Ukraine]. K.: Naukova dumka. 347. (In Russ.)

17. Patyka, V.P., Tarariko, O.G., ed. (2002). Ahroekolohichnyy monitorynh ta pasportyzatsiya sil's'kohospodars'kykh zemel': metodychno-normatyvne zabezpechennya [Agro-ecological monitoring and certification of agricultural land: methodological and normative maintenance]. K.: Fitosotsiotsentr. 35-37. (In Ukr.)

18. Yakist' gruntu. Vyznachennya vmistu rukhomykh spoluk marhantsyu (tsynku, kadmiyu, zaliza, kobal'tu, midi, nikelyu, khromu, svyntsyu) $v$ gruntiv buferniy amoniyno-atsetatniy vytyazhtsi $z$ rN 4,8 metodom atomno-absorbtsiynoyi spektrofotometriyi: DSTU 4770.1:2007 - DSTU 4770.9:2007 [Quality of soil. Determination of the content of mobile compounds of manganese (zinc, cadmium, iron, cobalt, copper, nickel, chromium, lead) in a soil in a buffer ammonium acetate extract with $\mathrm{pH} 4.8$ by atomic absorption spectrophotometry: DSTU 4770.1: 2007 — DSTU 4770.9: 2007]. (2007). Kyiv: Derzhspozhyvstandart Ukrainy. (In Ukr.)

19. Metodicheskiye ukazaniya po opredeleniyu tyazhelykh metallov $v$ pochvakh sel'skokhozyaystvennykh ugodiy $i$ produktsii rasteniyevodstva [Methodical instructions for the determination of heavy metals in soils of agricultural land and plant products]. M.: CINAO, 1992. 61. (In Russ.)

20. Dospekhov, B.A. (1985). Metodika polevogo opyta [Methodology of field experience]. M.: Agropromizdat. (In Russ.)

21. Il'in, V.B. (1995). Otsenka bufernosti pochv po otnosheniyu k tyazhelym metallam [Estimation of soil buffering with respect to heavy metals]. Agrokhimiya [Agrochemistry], 10, 109-113. (In Russ.)

22. Pshenytsya. Tekhnichni umovy: DSTU 3768-2010 [Wheat. Specifications: DSTU 3768-2010]. Kyiv: Derzhspozhyvstandart Ukrainy, 2010. (In Ukr.)

23. Perelman, A.I. \& Kasimov, G.N. (1999). Geokhimiya landshaftov [Geochemistry of Landscapes]. M.: Astreya. 768. (In Russ.)

\section{Authors}

Konovalenko Lyudmila Ivanovna - Candidate of Chemical Sciences, Senior Researcher, Department of Agricultural Production Technologies, Donetsk state agricultural science station of NAAS (Ukraine, 85307, Donetsk region, Pokrovsk, 1 Zashchitnikov Ukrainy St.; e-mail: cnzdiapw@ukr. net)

Bondareva Olga Braunovna - Candidate of Technical Sciences, Senior Researcher, Scientific Secretary, Donetsk state agricultural science station of NAAS (Ukraine, 85307, Donetsk region, Pokrovsk, 1 Zashchitnikov Ukrainy St.; e-mail: olbraun58dds@ukr.net)

Vinyukov Aleksandr Aleksandrovich - Candidate of Agricultural Sciences, Director, Donetsk state agricultural science station of NAAS (Ukraine, 85307, Donetsk region, Pokrovsk, 1 Zashchitnikov Ukrainy St.; e-mail: alex.agronomist@gmail.com). 